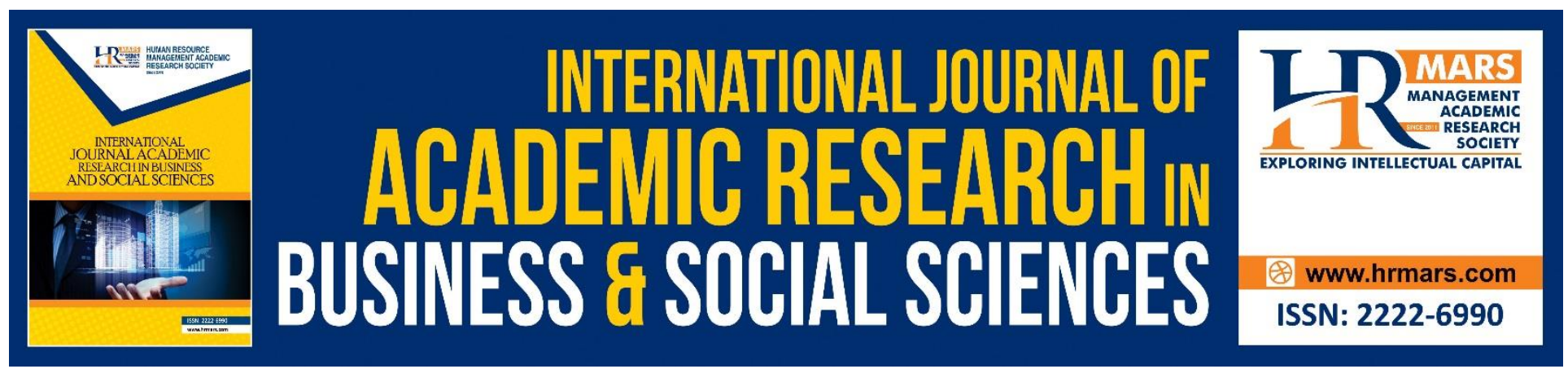

\title{
Write on with Comics
}

\section{Shanu Preeya a/p Thannimalai, Melanie a/p Selvaraj, Melor Md. Yunus}

To Link this Article: http://dx.doi.org/10.6007/IJARBSS/v9-i2/5544

DOI: $\quad 10.6007 /$ IJARBSS/v9-i2/5544

Received: 29 Jan 2019, Revised: 21 Feb 2019, Accepted: 03 March 2019

Published Online: 06 March 2019

In-Text Citation: (Thannimalai, Selvaraj, \& Yunus, 2019)

To Cite this Article: Thannimalai, S. P. a/p, Selvaraj, M. a/p, \& Yunus, M. M. (2019). Write on with Comics. International Journal of Academic Research in Business and Socal Sciences, 9(2), 283-299.

\section{Copyright: (c) 2019 The Author(s)}

Published by Human Resource Management Academic Research Society (www.hrmars.com)

This article is published under the Creative Commons Attribution (CC BY 4.0) license. Anyone may reproduce, distribute, translate and create derivative works of this article (for both commercial and non-commercial purposes), subject to full attribution to the original publication and authors. The full terms of this license may be seen

at: http://creativecommons.org/licences/by/4.0/legalcode

\section{Vol. 9, No. 2, 2019, Pg. 283 - 299}

Full Terms \& Conditions of access and use can be found at http://hrmars.com/index.php/pages/detail/publication-ethics 


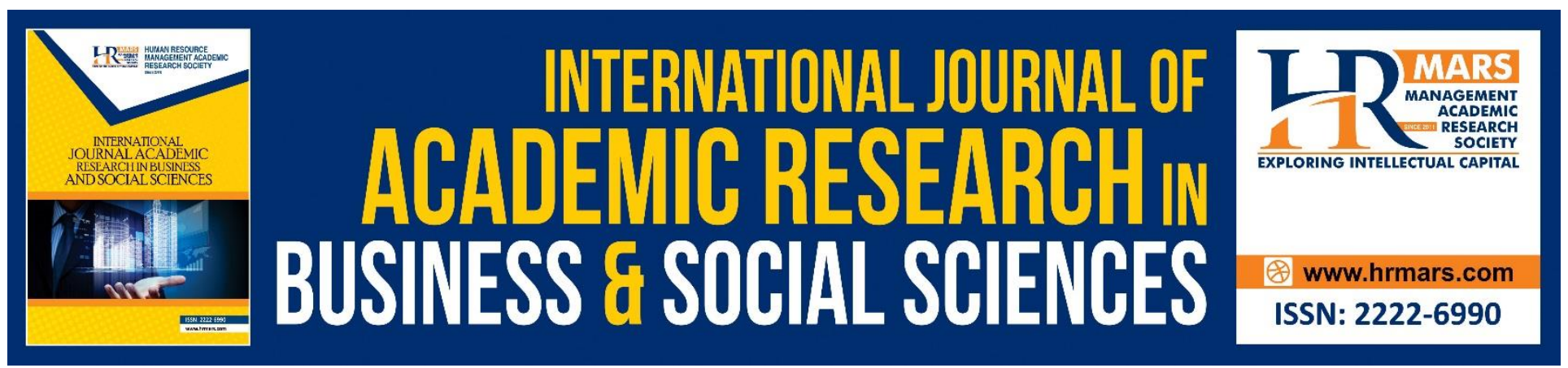

\title{
Write on with Comics
}

\section{Shanu Preeya a/p Thannimalai}

SK Ampang Pecah, Kuala Kubu Bharu, Selangor

Email:SHANU0805@outlook.com

\author{
Melanie a/p Selvaraj \\ SK Tengku Mariam, Batu Pahat, Johor \\ Email:meljude77@yahoo.com
}

\author{
Melor Md. Yunus \\ Faculty of Education, Universiti Kebangsaan Malaysia, 43600 (UKM), Bangi, \\ Selangor Darul Ehsan, Malaysia \\ Email:melor@ukm.my
}

\begin{abstract}
Teaching writing skills in ESL classrooms through the use of Information and Communication Technology (ICT) is still very discouraging despite the existence of many studies showing positive effects of using ICT in the teaching and learning process. In flow of the current technological trends, many efforts have been carried out worldwide to implement the use of ICT in 21st century ESL classrooms. However, Malaysian pupils have yet to master basic writing skills in accordance to the demands of the Malaysian Blueprint. Therefore, this research focused on the implementation of digital comics to emphasize on the writing of social expressions alongside inculcating interest in writing among the pupils. This mixed method research was conducted among 20 Year 5 respondents of intermediate proficiency from 2 different sub-urban schools in Kuala Kubu Bharu, Selangor and Batu Pahat, Johor. The data that was collected through document analysis, semi-structured interviews and observations were further analyzed to identify the outcome of using digital comics to improve pupils' writing of social expressions. It was proven, through this research, that the use of digital comics was successful in showing evident progress in the pupils' writing of social expressions as well as in sustaining their interest in the writing process. Therefore, it could be concluded that digital comics is an effective tool to increase pupils' ability to write a good variety of social expressions.
\end{abstract}

Keywords: ESL classrooms, Digital Comics, Writing Skills, Social Expressions, Interest 


\section{INTRODUCTION}

In this globalization era, the English language is growing to become a global language whereby its use is growing into becoming more of a requirement for individuals all over the world in a wide variety of work fields. Dunwill (2017) defines a global language as one that is conversed internationally and is not defined only by the nationals that use it, but also for its geographic extension and its use in government bodies, international organizations, business and trading, and diplomatic relations. According to Crystal (2003) as cited in Wang (2013), "there are two main ways the recognition is achieved: either by being designated the official language, or by being made a primary foreign language to be taught in schools."

The Malaysian Education Blueprint 2013-2025 emphasizes on empowering the use of ICT to promote quality education. Since Malaysians are avid users of the Internet, the ministry's aim of incorporating ICT in classrooms appears to be achievable. Despite the increasing application of ICT, Malaysian students demonstrate mediocre writing performances as far as the English language is concerned. This is affected by the perceptions that Malaysian students have on the importance of writing. Teachers are more focused on the communicative aspect of the language as they feel that writing is a tough skill to teach as students are bounded by grammar rules, writing conventions and the size of their vocabulary. This is supported by Neda, Marian \& Seyyed (2012), who found that "ESL teachers in Malaysia confirm the problems in writing development, especially in conventions, and punctuation." In order to help teachers throughout Malaysia overcome this mindset, it is a good idea to implement the use of digital comics in allowing students to practice writing in a more fun and familiar way.

\section{PROBLEM STATEMENT}

In Malaysia, primary school students are required to undergo a major academic assessment through the national UPSR examination at the end of their 6-year schooling period. In this examination, like most major examinations in Malaysia - PT3 and SPM, students are assessed mainly through writing. In the UPSR examination, where the students are required to write social expressions in written dialogue forms, students struggle to score in this section. This is supported by Puteh, Rahamat \& Karim (2010) who state that "Unfortunately, the results of the school as well as national level examinations show as if the learners have not fully mastered the basic aspects of the language especially in writing skills." Due to this realization, this research aims at introducing the use of digital comics to encourage pupils to gain interest in the writing process. This research focuses on a more basic writing skill whereby pupils will be guided to write conversational dialogues, emphasizing on social expressions, which will then motivate pupils to write more in depth substances such as essays. The use of digital comics along with the incorporation of popular social networking application, Instagram, has been brought into the limelight to improve students' writing of social expressions by encouraging varying responses and enhancing students' interest in writing.

The digital comics generator website, www.makebeliefscomix.com, is a website that was created by the author of Pocketdoodles, Bill Zimmerman. It is a creative, free-access online comics generator that allows students to freely design and create their very own comics. These comic 
creations can then be saved and e-mailed, which enables the students to revisit and share them. For this study, the sharing platform used is Instagram, a social media application where people post, like and share photos. This platform is a great tool to get the students to publicize their comics and get first-hand feedback from their friends on Instagram. The collaborative use of these two websites was carefully planned out based on how impactful they are at highlighting the learning process and address the evident issues, particularly in the writing aspect. This study aims to identify how the use of digital comics can encourage a variety of responses when writing social expressions and how it affects pupils' interest to learn the writing skill.

\section{LITERATURE REVIEW}

Writing in Malaysia is one of the crucial skills that pupils have to be proficient in in order to master the English language. It is one of the four language skills taught and tested at all levels. This is aligned with the second shift in the Malaysian Education Blueprint (2013-2015) which is to ensure every child is proficient in the national language as well as in the English language as it is the international language of communication. In other words, this shift enables pupils to master both languages, making English an important subject. The curriculum of teaching writing has been designed to enable pupils to produce different text types by the end of their primary school education. Their progress will then be assessed through the Primary School Achievement Test, also known as 'Ujian Pencapaian Sekolah Rendah' (UPSR), in the final year of primary schooling.

The UPSR English papers consist of two individual papers - one to assess pupils' comprehension and the other to assess their writing skills. Under Question 21 in the Comprehension paper, pupils are required to write social expressions based on the dialogues given. Pupils need to write complete sentences with proper spelling and punctuations. However, even after 6 years of education, Malaysian pupils still struggle to produce correct sentences with accurate writing mechanisms. Writing is a complex process of innovation as it involves idea generating, grammar, vocabulary mastery and the art of organizing the ideas cohesively. (Mohamad et al. 2018; Fareed et al. 2016; Firmansyah 2015). These shortcomings demotivate the pupils to engage themselves in writing activities. As a result, pupils are unable to show academic progress in writing. There are many factors contributing to this complexity. According to (Yunus \& Chan 2016; Fareed et al. 2016), this issue could be due to the teaching methods employed by the teachers, the types of writing activities opted in the classrooms, or lack of chances to practice writing.

\section{Social expression in Malaysian context}

The Malaysian Curriculum Development Centre emphasizes on language for interpersonal use. Language use for interpersonal purposes refers to the use of language to build relationships with peers through meaningful conversations. The aim, as stated in the Standard Document of Curriculum and Assessment (2015), is to equip pupils with basic English and enable them to communicate effectively in a variety of contexts. Therefore, to achieve this, a few objectives have been set. One of the objectives is that pupils should be able to communicate with their peers and adults confidently and appropriately in formal and informal situations. 
Thus, the social expressions section is taught to meet these objectives. In this context, social expressions are described as the way one produces his thoughts and feelings linguistically to the people around him. Social expressions can be taught in many different ways, with the most conventional way being through role plays and dramas.

\section{Benefits of Learning Social Expressions}

Teaching social expressions in the ESL classroom is crucial to Malaysian primary school pupils as it is one of the components which is tested in UPSR. The main purpose of this section is to enable pupils to produce correct and meaningful expressions as a response to the given situations. Thus, pupils learn to write using correct grammar to produce appropriate sentences and apply the accurate mechanics of writing. Writing mechanisms include punctuations, spellings and capitalizations which are crucial for producing quality writing. According to Isnin S. F. (2017), by possessing good technical writing skills pupils will be competent in communication skills.

Besides that, learning to write social expressions will assist pupils to generate ideas based on various situations. According to Crossley et al. (2016), children face more challenges to generate ideas in written form into oral production, as they will be more focused in other writing skills such as finger movement, letter writing, spelling, and grammar. Writing social expression responses helps pupils generate ideas and at the same time focus on the mechanics of writing. This maximises the cognitive process. Other than that, learning social expressions in the classroom enhances other language skills such as speaking skills among Malaysian pupils who are multiracial and come from various backgrounds. It helps pupils practice using basic expressions that can be used in their daily lives. This measure alleviates the fear of communication and promotes the practice of communication skills. Hence, this motivates them to use their communication skills in their daily lives. The inclusion of comic-like illustrations to aid their learning of social expressions creates a more fun experience. As stated by Klau (2015), the pictures in the comics facilitate vocabulary teaching besides aiding comprehension which helps the pupils memorize and recall words.

\section{Digital Comics}

Yablonsky (2016) defines comics as a form of sequential art which contains creative expression in a diverse discipline. It is an art and literary form that deals with the arrangement of pictures or images and words to narrate a story or dramatic idea. Comic strips are widely used in English classrooms. The use of cartoons in teaching has proven several advantages. These cartoon strips make English as a second language (ESL) classrooms more lively and interesting. Using comics in the ESL classrooms promote pupils' engagement, thus improves pupils' learning. According to Klau (2015), comics increase the motivation and engagement of pupils in the classroom and reduces feelings of being threatened. Besides that, comics can prolong pupils' attention span, and enhance pupils' communicative and linguistic competences. According to Marianti (2015), digital comics promote and develop analytical and critical thinking skills among pupils. Other than that, pupils learn English in more enjoyable and interesting ways because comics are in static form and possess intense language instruction so pupils can read the text at their own pace when compared to other forms of mass media (Drolet 2010). 


\section{Past Researches}

There are several studies done regarding the use of comics in the ESL classrooms. The studies identified used comics strips in teaching writing in ESL classrooms. Hamidah et al. (2015) conclude that the use of comic strips can improve the writing of narrative text skills among eight grade pupils. They found that comic strips could help pupils generate ideas in writing narrative essays.

In another study conducted by Maulana and Fitrawati (2017) on the use of comics in teaching reading found that pupils who were demotivated to read due to a fear of disappointment or failure in reading were seen engaged positively in reading. Thus, teaching reading using the new method of using comic strips, supported by a different teaching technique, had shown improvement in their attitudes towards learning reading. This strategy used helped the English teacher create a pleasurable surrounding in the classroom and the process of teaching and learning became more interesting for both the pupils and the teacher.

In Malaysia, there are very few studies involving the use of comics in teaching and learning, especially in primary schools. According to Krishnan and Othman (2016), their study was to see the effectiveness of using comics in increasing pupils' achievements and their higher order thinking skills. Pupils felt it was easy for them to remember Science facts and concepts using comics. It was reported that there was a significant increase in the achievement of the pupils in the tested topics. The pupils were able to sharpen their thinking skills, as they became active learners and the teachers were able to achieve the learning objectives effectively.

In another study conducted by Yunus et al. (2011), which was aimed at examining teacher trainees' perceptions of using digital comics in teaching writing ESL low achievers, clearly indicated that most of the surveyed teacher trainees had a positive perception of using ICT and digital comics in teaching ESL writing to low achievers. The majority of the respondents stated that digital comics have a lot of advantages that encourage pupils to write in English.

A study conducted by Ahamed and Harun (2016) focused on the designing of reading instruction, specifically through web comics, to assist pupils in comprehending written texts. They reported that the study was conducted due to current practices in the teaching of reading comprehension which focuses on reading from text books. Pupils have inadequate vocabulary thus resulting in incapability of comprehending a particular text. They believe that teachers need to be creative in designing reading instructions to be utilized in reading lessons to assist pupils with average proficiency in understanding a text when they read it.

A different study conducted by Rajendra (2018), he explored the advantages of graphic novels, also known as comics, which is used in Malaysian classrooms. It is reported that pupils enjoy comics as compared to traditional linear texts. It also stimulates the interest of reluctant readers and concluded that comics can be a creative pedagogical supplement in teaching and learning. 
These researches have all studied the use of comics in their digital form to observe how they improve pupils' mastery of various skills in the English language. They have indeed provided a positive viewpoint on the use of digital comics in the ESL classroom. Most of the researches mentioned, however, studied the use of the comics on the reading skill. Although some of these researches studied the writing skill, it was only the main aspect of the writing skill which was tested on - narrative texts. There is an evident research gap in this light. Therefore, this research aspires to provide a more practical view for ESL teachers whereby they will be able to comprehend how digital comics can guide primary-leveled pupils in the writing of conversational dialogues, stressing on social expressions in particular. It will offer a more practical approach to the teaching field within the Malaysian context.

\section{Underlying Theories}

It is crucial for Malaysian pupils to master their writing skills in order to achieve academic excellence in UPSR. In order to write social expressions, it is important for teachers to facilitate pupils by selecting appropriate strategies and activities. One of the ways to improve pupils' writing of social expressions is through digital comics. As this research emphasizes the use of digital comics in the ESL classroom, it indirectly promotes pupils' cognitive development. The social cognitive theory is highly involved in the teaching and learning process. This theory explains the different mental processes as learners are influenced by both intrinsic and extrinsic factors, which eventually bring about learning in an individual (Bandura 1986).

In this study, to create the comics and determine the appropriate responses, pupils were influenced by the two key factors - cognitive factors and behavioural factors. The cognitive or personal factors that affect the pupils are their level of knowledge and personal expectations towards the activity, whereas behavioural factors include their skills in executing what they know by developing and creating ideas. Since the pupils were required to create their own comics based on their prior knowledge and upload their creations on Instagram, this encouraged them to learn from their peers and produce their best work and regulate their own performance through intrinsic and extrinsic motivation. Active cognitive processes take place when pupils have to design the comics and brainstorm with their peers to generate ideas on ways to develop appropriate responses for their comic creations.

Besides the Social Cognitive Theory, another underpinning theory adopted in this study is the constructivist theory. This theory emphasizes on active learning in a constructive manner. In other words, pupils must be provocative, collaborative and communal to create their own understanding by experiencing things and linking new information to prior information (Bruner 1996). In a classroom context, pupils learn through active techniques involving discoveries and cultural elements. In short, constructivism taps into and triggers the pupil's innate curiosity about the surroundings and how things work. In relation to this study, pupils worked in pairs to construct sentences based on their prior knowledge of sentence construction. Pupils then experienced active learning when they could create a series of creative comics from scratch and share them on Instagram to obtain feedback from their teachers and peers. In conclusion, these activities had intertwined two language learning theories to maximize pupils' potential. 


\section{METHODOLOGY}

This research adopts the mixed methods research design whereby both quantitative and qualitative data were utilized cohesively in order to present a more complete utilization of data as compared to separate quantitative and qualitative data collection and analysis. This is in accordance to Cresswell (2011) who explains that mixed methods require researchers to "collect, analyze, and integrate both quantitative and qualitative data in a single study or in a sustained long-term program of inquiry to address their research questions." The mixed method allows for convincing results as the data collected comprise of both quantitative and qualitative characteristics.

By adopting the mixed mode research method, the data collected was triangulated as they were collected through document analysis, semi-structured interviews as well as observations. The sampling for this study comprised of 20 Year 5 pupils from 2 different sub-urban schools in Kuala Kubu Bharu, Selangor (School X), which is within the central region and Batu Pahat, Johor (School Y), which is in the southern region of Malaysia. These pupils have an intermediate level of proficiency and perform on average scale in their English tests. Due to the fact that the respondents involved were from 2 different schools, Figure 1 below shows which schools they are from.

Table 1: Demographics of the Respondents

\begin{tabular}{|c|c|c|c|}
\hline Respondent & School & Gender & Age \\
\hline $\mathrm{R} 1$ & \multirow{10}{*}{ School X } & Female & \multirow{20}{*}{$\begin{array}{c}11 \\
\text { (Year 5) }\end{array}$} \\
\hline $\mathrm{R} 2$ & & Female & \\
\hline R3 & & Male & \\
\hline $\mathrm{R} 4$ & & Male & \\
\hline R5 & & Female & \\
\hline R6 & & Male & \\
\hline R7 & & Female & \\
\hline $\mathrm{R} 8$ & & Female & \\
\hline R9 & & Male & \\
\hline R10 & & Male & \\
\hline $\mathrm{R} 11$ & \multirow{10}{*}{ School Y } & Female & \\
\hline $\mathrm{R} 12$ & & Female & \\
\hline R13 & & Female & \\
\hline R14 & & Female & \\
\hline R15 & & Female & \\
\hline R16 & & Female & \\
\hline R17 & & Female & \\
\hline R18 & & Female & \\
\hline R19 & & Female & \\
\hline R20 & & Female & \\
\hline
\end{tabular}


As shown in Table 1, the respondents of this study consist of more female pupils. The reason why School $X$ has both male and female respondents, and School $Y$ only has female respondents is because School $X$ is a co-ed school, whereas School $Y$ is a girls' school. In this research, the respondents were required to collaboratively create their individualized comic creations based on the given situations through the www.makebeliefscomix.com comic generator website. They were paired throughout the process to enable them to collaborate and come up with better dialogue responses. However, their improvements in achievement were recorded individually. The three data collection methods used are specifically selected to provide clarification on the proposed research questions. The pre and post test results will be able to show evidence of the respondents' improvements post-intervention so as to respond to the first research question, whereas the observations and interviews will be able to reaffirm the second research question which is to show the pupils' interest in the writing process.

The respondents were first made acquainted to the website itself as it was unfamiliar to them. The next day, the respondents were introduced to 5 different situations - Introduction, Permission, Apology, Congratulation and Direction. Each topic was introduced in one week intervals. After a topic was introduced, the respondents were required to create their first comic panel. The teacher would then allow the respondents' time to brainstorm ways on how to lengthen their responses for the second panel. Examples of the respondents' creations are discussed further in the findings section. After completing both panels, the respondents e-mailed their work to the teacher for correction purposes. Once the teacher had corrected their mistakes, the respondents were asked to make the necessary amendments based on the given feedback and finalize their comic creations. They were then given the opportunity to share their work on the joint Instagram account which was created specifically for this research, 'Our_Comic_Creations'. The respondents were thereafter encouraged to comment and provide feedback on the works of the other respondents from both schools. The later mentioned steps would repeat for each situation that was taught.

\section{FINDINGS AND DISCUSSION}

The two main objectives of this research are to identify the effectiveness of using digital comics in writing social expressions among Year 5 pupils as well as to develop their interest in writing. The data obtained in result of the conduct of this study showed positive inclination towards both objectives. The data will be explained based on the objectives in the following sub-sections.

\section{The Effectiveness of Digital Comics in the writing of Social Expressions}

Based on the pre and post test that were conducted, it was proven that the use of digital comics did show an improvement in the respondents' ability to write social expressions. The digital comics generator website, www.makebeliefscomix.com, provided a comprehensive outlet for the respondents to create creative situations and come up with suitable dialogues based on the comics that they had created. Therefore, the respondents were able to retain the information better. The graphs below display a comparison of the respondents' results of the pre and post tests. 
Table 2: Pre and Post-test Results

\begin{tabular}{c|c|c|c|c}
\hline Respondent & $\begin{array}{c}\text { Pre-test Result } \\
\text { (\%) }\end{array}$ & $\begin{array}{c}\text { Post-test Result } \\
\text { (\%) }\end{array}$ & Increment (\%) & $\begin{array}{c}\text { Overall Increment } \\
\text { (\%) }\end{array}$ \\
\hline R1 & 50 & 80 & 30 & \\
\hline R2 & 55 & 85 & 30 & \multirow{3}{*}{$\mathbf{3 8 . 5}$} \\
\hline R3 & 40 & 90 & 50 & (School X) \\
\hline R4 & 40 & 95 & 55 & \\
\hline R6 & 65 & 85 & 20 & \\
\hline R7 & 35 & 90 & 55 & \\
\hline R8 & 45 & 95 & 50 & \\
\hline R9 & 50 & 75 & 25 & \\
\hline R10 & 35 & 75 & 40 & \multirow{2}{*}{ 40.0 } \\
\hline R11 & 55 & 85 & 30 & (School Y) \\
\hline R12 & 55 & 100 & 55 & \\
\hline R13 & 45 & 90 & 35 & \\
\hline R14 & 60 & 85 & 40 & \\
\hline R15 & 75 & 90 & 30 & \\
\hline R16 & 60 & 100 & 25 & \\
\hline R17 & 45 & 85 & 25 & \\
\hline R18 & 60 & 85 & 40 & \\
\hline R19 & 35 & 95 & 55 & \\
\hline R20 & 40 & 90 & 50 & \\
\hline & & 100 & & \\
\hline
\end{tabular}

The content of the test comprised of 2 questions under each category, with a total of 10 questions and worth 20 marks as a whole. Each question is worth a minimum of 0 marks and a maximum of 2 marks with aspects like content, spelling and punctuation being focussed on as stated in the UPSR marking scheme. Therefore, through thorough analysis of the scores, as can be seen in the table, it can be said that the respondents have shown vast improvements in their ability to score in such questions as compared to before the intervention. More respondents were able to obtain full marks for most of the questions and none had obtained 0 or 1 mark for any of the questions, which contributed a lot to their overall test scores.

The total amount of increment calculated as a whole is $38.5 \%$ for School $X$ and $40.0 \%$ for School Y. This shows a closely similar amount of increase by the respondents from both schools. These results prove that the use of digital comics through the www.makebeliefcomix.com platform was effective in improving the respondents' writing of social expressions. They were able to come up with more elaborate and higher quality responses instead of superficial single-word answers like 'Yes' or 'No' or 'Sorry' as seen in Figures 1 and 2 below. The nature of the website allowed the pupils to think creatively and critically when producing their comic strips. The respondents' enjoyed being able to create the comics together with their peers as it allowed them to brainstorm for more creative ideas 
which enhanced the learning process. This is in line with the findings of a research conducted by Yunus, Salehi \& Embi (2012), aimed at identifying teacher trainees' perceptions on the application of digital comics, which showed that the respondents considered digital comics "easy to use and capable of encouraging students to write creatively".

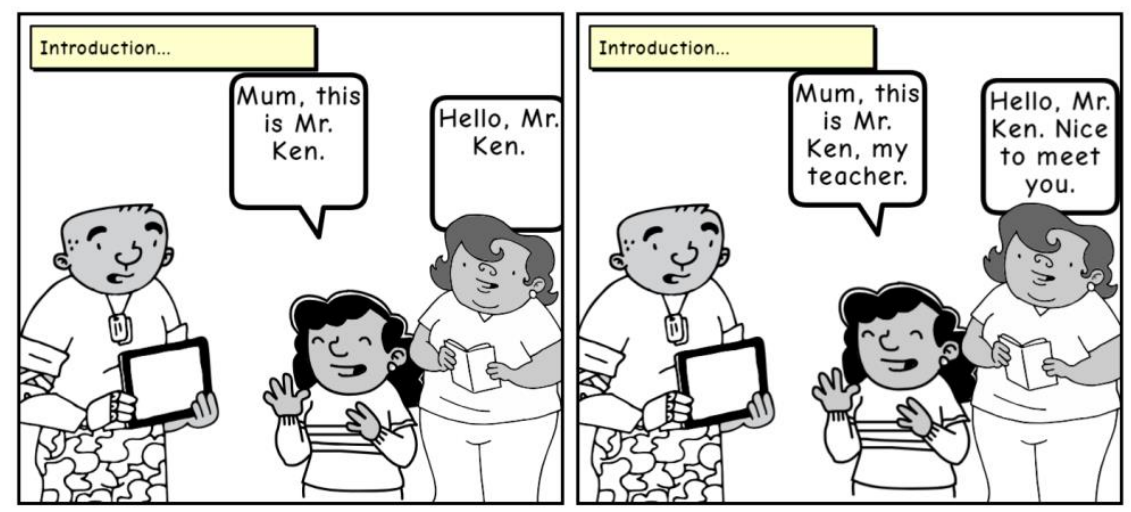

This comic was created at www.MakeBeliefsComix.com.

Figure 1: R1 and R2's comic creation for 'Introduction'
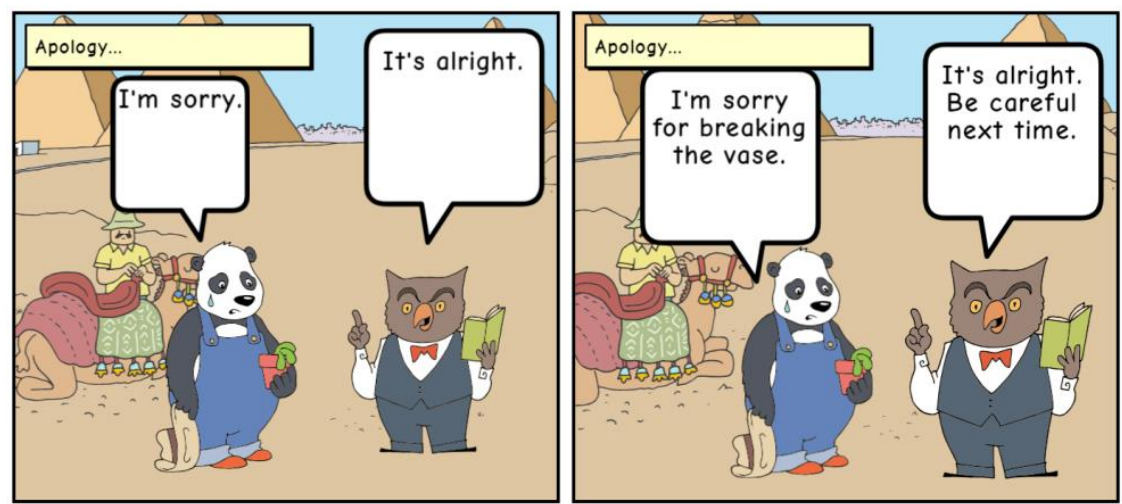

This comic was created at www.MakeBeliefsComix.com.

Figure 2: $R 9$ and R10's comic creation for 'Apology'

Figures 1 and 2 show how the respondents were able to expand their brief responses and create more in depth responses. After completing the first panel, the respondents were allocated time to brainstorm ways to lengthen their responses appropriately. This process was more studentcentered as the teacher served more as a facilitator that would only provide guidance whenever necessary. Based on an experimental study conducted by Malkawi \& Smadi (2017), the results showed that the brainstorming method was able to raise the students' abilities and enhance the positive interaction relationship between the teachers and students and between the students themselves which related positively to their achievement. 


\section{Pupils' interest in writing}

This second objective was answered by the interviews conducted with the respondents as well as the observations made throughout the intervention sessions. The interviews were conducted postintervention which gave an overall view of the respondents' thoughts and opinions on the whole process. The interview and observation findings were summarized into a few sub-themes as explained in the following paragraphs.

The selected intervention, the generation of digital comic creations through the www.makebeliefcomix.com platform, was said to be an easy and hassle-free process. In the interview, Respondent 3, during the interview, mentioned that it was easy to grasp and navigate the website: "... it so easy to use. No stress!" (R3, a male respondent from School X). The respondents agreed that the website was very user-friendly and comprehensive. This made the process smoothsailing for both the teacher as well as the respondents as familiarizing themselves with the website wasn't a daunting and time-consuming task. One of the major drawbacks that hinders teachers from wanting to use ICT, according to Venkatesh \& Davish (2000) as cited in Ghavifekr, Kunjappan, Ramasamy, et.al. (2016), is the Perceived-ease-of-use (PEOU) which is the degree that they believe that using a particular website or application would not cost effort. The application of the userfriendly www.makebeliefcomix.com platform in this research eliminates all possibilities of the teachers and respondents experiencing PEOU as observed through the interview response mentioned above.

Besides that, the respondents also found the platform to be very unique and interesting. It was a new experience for them as they had never been exposed to such teaching and learning resources. This creates an authentic learning experience and therefore increases curiosity within the respondents when it comes to exploring the website and creating the comics. According to Respondent 9 (a male respondent from School X), "It was so so sooo fun. I like the character. They so funny." to which Respondent 10 (a male respondent from School X) responded, "A'ah. Kungfu panda tu the so funny." [Yes. The Kungfu panda character was so funny.] In a study conducted by Graham (2011), the researcher made use of the www.makebeliefcomix.com as a supporting tool to help his respondents write through a gap-fill activity. His research displayed that one of the first grade classes that had been tested on with the comics and writing activities was very enthusiastic about writing despite the fact that they had not even covered the alphabet at that time. This proves that young learners have highly inquisitive and would easily be attracted to new experiences as seen in this study as well.

Respondent 15 (a female respondent from School Y) also mentioned that it was nice to have many options for the types of characters and background designs. "The background dengan characters best sebab boleh pilih. Ada banyak." [The background and the characters were great because there were so many we could choose from.] (R15, a female respondent from School Y). The www.makebeliefcomix.com website is constantly updated to provide better quality experience to users. A main advantage when using this website for the teaching of social expressions is that each character can portray a maximum of 4 different facial expressions. This is important as respondents 
were able to plan out their dialogues and situations based on the expressions portrayed by the characters and vice versa. This encouraged the use of creative and critical thinking because there was more liberty. Generally, all of the respondents were very attracted to the illustrations included in the website. Since creating comics is an inclusion of arts in the ESL learning process, the fact that "the arts naturally lend themselves to multicultural and visual teaching and learning, which enhance LEP/ELLs access to language acquisition and cross-cultural education." (The New York State Education Department, 2010) justifies the use of comics. This increased the momentum of the lessons and made them more engaging. The respondents were much more interested to participate in these lessons compared to traditional chalk and talk or textbook-based lessons. This created a more stress-free and comfortable learning environment for the respondents.

Apart from that, with the incorporation of the social media platform, Instagram, the respondents were motivated to create better comics as they were aware that their work would be displayed for the viewing of the general public. An observation made during one of the intervention sessions showed that $\mathrm{R} 7$ and $R 8$ (two female respondents from School $\mathrm{X}$ ) were discussing how their comics have to be perfectly arranged and accurate because they want to show them to their friends. (Observation on the $9^{\text {th }}$ of October 2018). The use of social media is more of a necessity now amongst the younger generation. Therefore, attempts to make use of it in the teaching and learning process will not only be able to draw their interest and attention, but it will also be able to provide a different outlook on the platform itself.

The respondents also appreciated the fact that they were given a chance to work collaboratively with a partner throughout the process. Since the respondents have an intermediate level of proficiency, they were happy to be working on the comics together with their peers. "I like pair work because I can do with my friend." (R1, a female respondent from School X) An observation was also made in relation to collaborative learning which showed evidence of scaffolding. R18 (a female respondent from School Y) was explaining the difference between 'borrow' and 'lend' to R17 (a female respondent from School Y) as she didn't know which to use when. (Observation on the $25^{\text {th }}$ of September 2018) This shows that the respondents were able to develop a support system amongst themselves whereby they were willing to help their partner as long as they felt assured and confident of their own answers. Curtain \& Dahlberg (2010) as cited in Cordeiro (2017) stated that "pair work activities stimulate the ability to work in cooperation, provide opportunities for language use, natural language practice and two-way communication."

Based on the statements mentioned above, it can be seen that the application of digital comics has indeed fuelled the respondents' interest in the learning process. The respondents were excited to learn through the use of comics, which increases their enthusiasm and eliminates their fear of learning the English language.

\section{CONCLUSION}

It is proven through many past studies that digital comics are an effective innovation to the traditional language learning classroom that provides students' with a hands-on learning experience through 
ICT. The findings of this research have proven that digital comics are capable of increasing students' ability to respond to social expressions in a variety of ways alongside increasing their interest and motivation to write. Apart from these two aspects, the use of digital comics has also benefited the respondents by giving them a new perception towards the learning of the English language. The integration of Instagram had also provided a more exciting learning experience for them.

Despite the many benefits of the application of digital comics, both School $X$ and School $Y$ were sub-urban schools, which contributed to a number of inadequacies mainly in relation to technical errors such as weak internet connection and inadequate facilities. This gave rise to a lot of time-constraint issues throughout the research. Nevertheless, these issues are quite approachable as they can be solved through better time-management.

This research that is based on the constructivist theory opens a window of opportunities for both teachers and pupils to explore the writing skill from a different and more approachable perspective. It introduces a more varied learning platform through the www.makebeliefcomix.com generator, which provides an authentic, creativity-inducing learning experience for struggling ESL learners. It is hoped, through this research, that pupils will be able to increase their motivation and self-confidence in improving their proficiency in the English language, particularly in the writing skills through the use of comics. Malaysian ESL teachers should be more proactive in aiming to apply creative, innovative, and substantial techniques to attract their pupils' attention and interest. This research will be able to serve a new teaching approach to ESL teachers.

For further research purposes, since this study focuses on improving the pupils' writing skills on conversational dialogues, the website can also be used to improve pupils' listening and speaking skills by turning the digital comics into animated comics whereby the pupils can record their voices and animate the characters to create short comic clips. This will give digital comics an elevated face, which will not only attract the pupils' attention, but also encourage them to communicate with one another. They would be able to improve their confidence in utilizing the language this way. 


\section{REFERENCES}

Ahamed, A. B. \& Harun, R. R. N. S. (2016). The principles adopted in designing the web comics to assist lower secondary students with reading comprehension. International Journal of Academic Research in Business \& Social Sciences, 6(11). DOI: 10.6007/IJARBSS/v6-i11/2458

Bandura, A. (1986). Social foundations of thought and action. New Jersey: Engelwood Cliffs.

Bruner, J. S. (1996). The culture of education. Cambridge, MA: Harvard University Press.

Creswell, J.W. "Steps in Conducting a Scholarly Mixed Methods Study" (2013). DBER Speaker Series. 48. http://digitalcommons.unl.edu/dberspeakers/48

Council of Europe (2001). Common European Framework of Reference for Languages: Learning, Teaching, Assessment. Cambridge: Cambridge University Press.

Cordeiro, M. C. (2017). Pair Work for Developing Speaking Skills. Unpublished Master's Thesis, University of New Lisbon, Lisbon.

Crossley, S. A., Muldne, K. \& McNamara, D. S. (2016). Idea generation in student writing: computational assessments and links to successful writing. Written Communication 2016, Vol. 33(3): 328-354. DOI: 10.1177/0741088316650178

Drolet, C. A. (2010). Using comics in the development of efl reading and writing. TESOL Review, 123(140).

Dunwill, E. (2017). Why Has English Become A Global Language? Retrieved from https://www.wesrch.com/gp/why-has-english-become-a-global-language-2954

Fareed, M., Ashraf, A., \& Bilal, M. (2016). ESL learners' writing skills: Problems, factors and suggestions. Journal of Education and Social Sciences, 4(2), 81-92.

Firmansyah, A. (2015). The influence of mind mapping technique and students' attitude toward students' ability in writing a recount text of the eighth grade students of state junior high school 45 palembang. RIPTEKSI KEPENDIDIKAN PGRI.

Hamidah, N., Usman, S., \& Muhsin (2015). Improving writing skill of the eight graders through comic strip. Journal of English Language Teaching Society (ELTS), 3(2).

Isnin, S. F. (2017). Exploring the needs of technical writing competency in english among polytechnic engineering students. International Journal of Academic Research in Business and Social Sciences. DOI: 10.6007/IJARBSS/v7-i12/3594 
Graham, S. (2011). Comics in the Classroom: Something to be taken seriously. Language Education in Asia, 2(1): 92-102.

Klau, R. O. (2015). Using comic strips to improve the speaking skills of grade viii students of smp in 15 Yogyakarta in the academic year of 2013/2014 (Doctoral dissertation, Yogyakarta State University).

Krishnan, S. \& Othman, K. (2016). The effectiveness of using comic to increase pupils' achievements and higher order thinking skills in science. International Journal of English and Education. Vol. 5(3): 281-292.

Malaysian Education Blueprint. (2013-2025).

Malwaki, N. \& Smadi, M. (2017). The Effectiveness of Using Brainstorming Strategy in the Development of Academic Achievement of Sixth Grade Students in English Grammar at Public Schools in Jordan. International Education Studies Canadian Center of Science and Education, 10.

Marianthi, V., Boulodakis, M., \& Retalis, S. (2016). From digitised comic books to digital hypermedia comic books: their use in education. Piraeus: University of Piraeus.

Maulana, Y., \& Fitrawati, F. (2017). Teaching reading by using comic strips to improve junior high school students'comprehension. Journal of English Language Teaching, 6(1): 124-131.

Mohamad, M., Ghazali, N., \& Hashim, H. (2018). Secondary School Students' Perceptions on the Use of Google+ towards Improving ESL Writing Skills. International Journal of Emerging Technologies in Learning (iJET), 13(09): 224-238.https://doi.org/10.3991/ijet.v13i09.8479

Neda, G., Marian Edwina, M. \& Seyyed Hossein Kashef. (2012). Investigating Malaysian ESL Students' Writing Problems on Conventions, Punctuation and Language Use at Secondary Level. Journal of $\begin{array}{llll}\text { Studies } & \text { in } & \text { Education, } & \text { 130-143), }\end{array}$ http://www.macrothink.org/journal/index.php/jse/article/viewFile/1892/1733.

Puteh, S. N., Rahamat, R. \& Karim, A. A. (2010). Writing in the Second Language: Support and Help Needed by the Low Achievers. Proceedia Social and Behavioural Sciences, 7(C): 580-587. https://core.ac.uk/download/pdf/81113355.pdf

Rajendra, T. R. (2018). Multimodality in Malaysian schools: The case for the graphic novel. MOJES: Malaysian Online Journal of Educational Sciences, 3(2): 11-20.

Wang, H. S. (2013). Global English As A Trend in English Teaching. Intercultural Communication Studies, XXII(1): 26-32. 
Yablonsky, M. (2016). Text and image in translation. Pedagogical University of Cracow, Poland CLEaR, 2016, 3(2), ISSN 2453-7128 40. DOI: 10.1515/clear-2016-0013

Yunus, M. M., \& Chan, C. H. (2016). The use of mind mapping strategy in Malaysian University English test (MUET) writing. Creative Education, 7(04): 619-626. DOI: 10.4236/ce.2016. 74064.

Yunus, M. M., Salehi, H. \& Embi, M. A. (2012). Effects of Using Digital Comics for Writing. Research Journal of Applied Sciences, Engineering and Technology, 4(18): 3462-3469.

Yunus, M. M., Salehi H., Tarmizi A., Idrus S. \& Balaraman, S. (2011). Using digital comics in teaching ESL writing. WSEAS. US: 53-58. 